\title{
Geomorphology and its implication in urban groundwater environment: case study from Mumbai, India
}

\author{
V. R. Rani · H. S. Pandalai · K. S. Sajinkumar • \\ A. P. Pradeepkumar
}

Received: 26 September 2013/ Accepted: 20 February 2014/Published online: 14 March 2014

(C) The Author(s) 2014. This article is published with open access at Springerlink.com

\begin{abstract}
Landforms of Mumbai Island have been largely modified by the urban sprawl and the demand for groundwater will increase exponentially in the future. Quality and quantity of groundwater occurrence in island are highly influenced by the geomorphic units. As this metropolis receives heavy rainfall, the area rarely faces the issue of water scarcity, nevertheless, quality always remains a question. The landforms of Mumbai Island have been shaped by a combination of fluvial, denudational and marine processes. These landforms are categorized into two broad zones on the basis of its influence in groundwater occurrence. Denudational landforms are categorized as runoff zones whereas the other two are categorized as storage zones. This classification is on the basis of occurrence and storage of groundwater. Mumbai Island is exposed to frequent sea water incursion and groundwater quality has deteriorated. The varied hydrogeological conditions prevalent in this area prevent rapid infiltration. This combined with the overextraction of groundwater resources for agriculture and industry has caused serious concern about the continued availability of potable water. This study aims at validating the geomorphic classification of the landforms with hydrogeochemistry and borehole data
\end{abstract}

V. R. Rani · H. S. Pandalai

Department of Earth Sciences, Indian Institute of Technology, Mumbai 400 076, India

K. S. Sajinkumar $(\varangle) \cdot$ A. P. Pradeepkumar

Department of Geology, University of Kerala,

Thiruvananthapuram 695 581, India

e-mail: sajinks@gmail.com

Present Address:

V. R. Rani

Central Ground Water Board, Thiruvananthapuram 695 004, India and it proved that geomorphology corroborates with groundwater chemistry and subsurface geology.

Keywords Mumbai · Groundwater · Geomorphology · Sea water incursion · Hydrogeochemistry

\section{Introduction}

Mumbai Island is one of the most intensely urbanized and industrialized regions of the world. It is included in the United Nations (UN) list of 'megacities' (UN redefined a 'megacity' as a city with a population of at least ten million people; Brockeroff 2000). The population of Mumbai has also gradually increased to become the fourth highest in the world-20.04 million (United Nations 2010). The island of Mumbai usually experiences greater demand for highquality groundwater than other areas due to this increasing population and because of the industrial boom along the coastal belt as well as due to the demands of agriculture in the flat fertile areas (Rani 2004). Moreover, groundwater resources assume considerable importance in this area because the monsoonal rainfall is limited to a four-month period (Limaye 2010), while the water demand for the rest of the year is met by the groundwater. In Mumbai, frequent water shortages are the result of a combination of issues: altered seasonality of rainfall, floods, salt water intrusion and the contamination due to the poor drainage and wastewater systems (Murthy et al. 2001; Nair 2009). Ground and surface waters in Mumbai are polluted due to the dumping of sewage and industrial effluents (Gupta 2009). Groundwater quality in the deeper regions of the aquifer is brackish to slightly saline in Colaba, Dharavi, and Khar which could be attributed to seawater incursion (MPCB 2011). High concentrations of pollutants exist in 
many places near the creek area (Haque et al. 2012) and its content has exceeded the prescribed limits. In addition, various alkali and dye industries are responsible for mercury pollution in Thane Creek. Moreover, various effluents from oil refineries and reactors, as well as fertilizer residues have polluted the groundwater (Sabnis 1984; Zingde and Sabnis 1989).

The urban sprawl together with rapid industrialization around this coastal city has modified the landforms to a great extent, which in turn has profound effect on groundwater systems. Landforms are the base for human activity and they are continuously modified. Understanding the geomorphic processes and the landscape helps us to plan land development and management in a better way. The majority of "hotspots" of groundwater depletion due to the overextraction were found in the areas of coastal megacities in the developing countries like Mumbai (Sekovski et al. 2012), though there exists a framework for groundwater extraction mentioned by the Government of Maharashtra Act (1993). The effect of urbanization on groundwater systems is dependent on the geological and hydrogeological setting (Barron et al. 2012) apart from the geomorphic setting.

A study about the geomorphic set up of an area, particularly a reclaimed and amalgamated island like Mumbai which has become the hub for all the developmental activities, has paramount importance as the majority of the population depends upon groundwater. The study aims at delineating the different geomorphic landforms on the basis of its hydrogeomorphic characteristics. These delineated landforms are further characterized by their hydrogeochemistry and subsurface geology. A number of studies on the hydrogeochemistry of Mumbai have been conducted (cf. Naik et al. 2007; Tirumalesh et al. 2010; Kamble and Vijay 2011) and the use of GIS in such studies explored (Anbazhagan and Nair 2004; Shankar and Mohan 2006). But a study, melding hydrogeomorphology, hydrogeochemistry and subsurface geology, has not been attempted so far and the present study may be a first of its kind. This study also proves the need for a macro-analysis of geomorphology for better management of groundwater resources.

\section{Study area}

Mumbai Island is located on the western coast of India (Fig 1) and experiences a tropical climate with copious rainfall. Geographically it lies between North latitudes $18^{\circ} 50^{\prime}$ and $19^{\circ} 18^{\prime}$ and East longitudes $72^{\circ} 45^{\prime}$ and $73^{\circ} 03^{\prime}$. The study area is bounded by Vasai creek to the north, Thane creek to the east and Arabian Sea to the south and west. The creeks of Thane and Vasai separate this island from the mainland. Besides the Thane and Vasai creeks, Manori and Malad creeks are other smaller creeks on the east of Mumbai Islands. The creeks are the sites where six major streams which traverse the length and breadth of Mumbai Island debouch. The area is densely populated and highly urbanized and is characterized by industrial, commercial and residential land uses. Vast regions of the Mumbai Island are also covered by dense forests. Hilly areas are characterized by moderate to thick vegetation and many such areas have been designated as reserve forests. Three large reservoirs occur in this island like Tulsi, Vihar and Powai. Agriculture and fishing are the major occupations. Salt panning is another important activity.

\section{Methodology}

The present study focuses on the study of role of geomorphology on groundwater occurrence. A macro-analysis of geomorphology was carried out through field studies supplemented with Survey of India (SOI) topographic sheets on 1:50,000 scale and remotely sensed data (IRS1C LISS III digital data). The geomorphic features identified were classified on the basis of hydrogeomorphic characteristics. These categorized zones are further validated through hydrogeochemistry of groundwater (analysis carried out as per APHA 1998) collected from both dug well and bore wells and sampled from different geomorphic terrains. Further, this was validated with the subsurface geology. The study, on a whole, proved that the geomorphic classification of landforms by field studies on the basis of groundwater occurrence was well validated with hydrogeochemistry and subsurface geology. The geomorphology not only tells the tale of the quantity but also the quality of groundwater occurrence.

\section{Geological setup}

Mumbai Island forms a part of Deccan Volcanic Province (DVP). DVP represents the remnants of one of the largest volcanic events on earth and is one of the best studied continental flood basalt provinces of the world. It originally covered an area of 1.5 million sq. km. (Krishnan 1982) with a total erupted volume of $2 \times 10^{6} \mathrm{~km}^{3}$ (Krishnan 1960; Pascoe 1964; Rao et al. 1978). The geological formations found in Mumbai include the Deccan Basalts and its acid variants, volcanic tuffs, intertrappean sediments, dykes, laterite and alluvium. The geology of Mumbai Island is rather unusual compared to that of the main Deccan flood basalt province, particularly the Western Ghats in several aspects (Sukeshwala and Poldervaart 


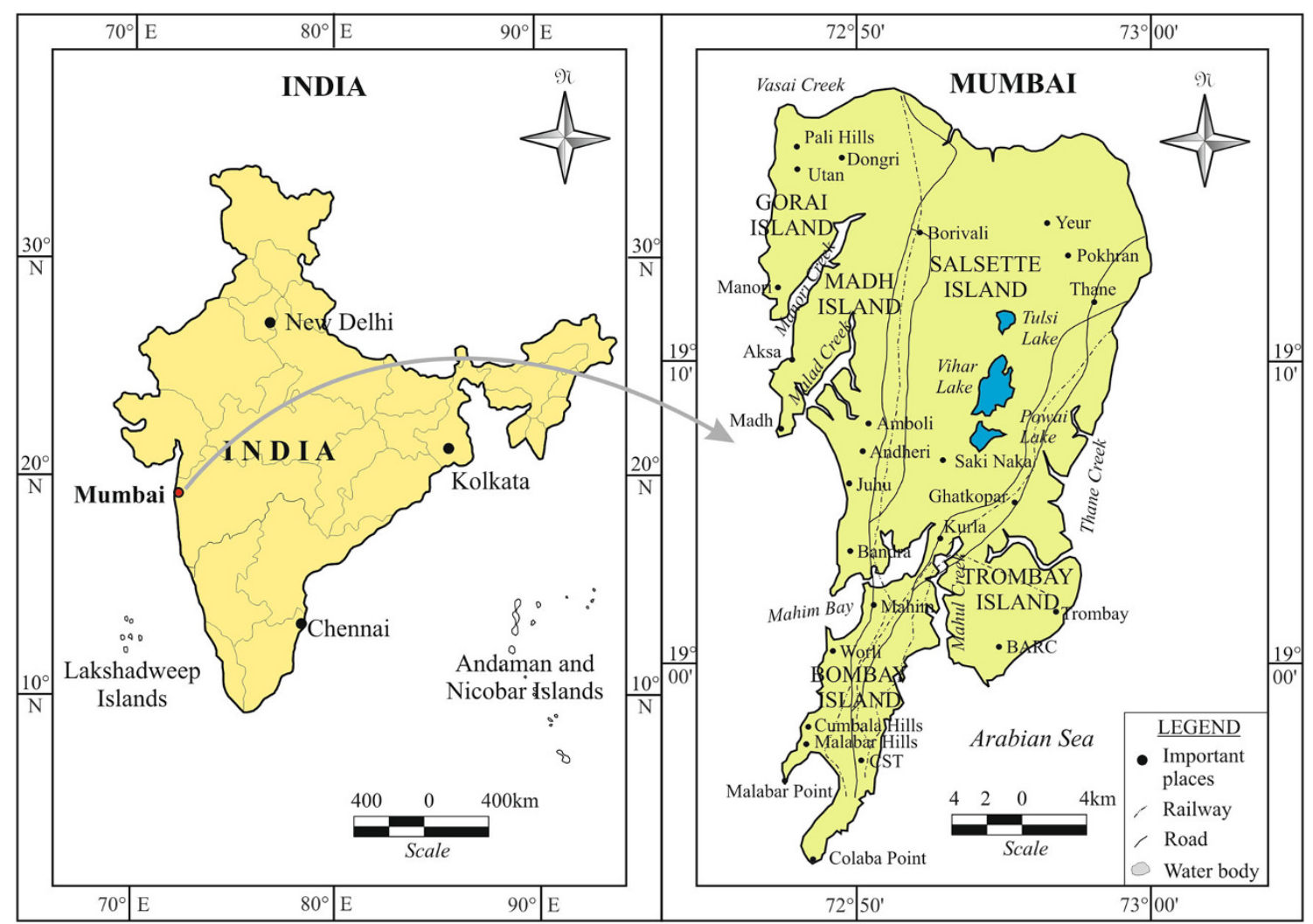

Fig. 1 Location map of the study area

1958; Sethna 1981, 1999; Sheth et al. 2001). Important differences include.

(1) The common occurrence of sedimentary intertrappeans, red boles and weathering profiles

(2) Sub-aqueous nature of the lava flows indicated by pillow structures, spilitic petrography and the presence of hyaloclastics (Sethna 1999)

(3) Representation of the intrusive phase of basic magma in the form of dyke swarms and plugs

(4) Association of acidic (rhyolite) and intermediate (trachyte) rock, often considered differentiates of the Deccan trap basaltic magma

(5) Occurrence of a large column of basic and acidic tuff and

(6) Pronounced westerly (seaward) dips up to $25^{\circ}$ unlike the horizontal lava pile of the Western Ghats (Auden 1949; Sheth 1998).

The Mumbai Island originally consisted of seven separate islands, separated from one another by swamps. These swamps were reclaimed, giving rise to a single landmass at the end of 18th century. This landmass is the old Mumbai city (Fig. 2). The Salsette Island to the north and the Trombay Island to the east were separated from the Mumbai Island by the Mahim and Mahul creeks, respectively. The Madh and Gorai Islands in the west were separated from the Salsette Island by the Malad and Manori Creek.

The Mumbai Island has ridges along its western and eastern sides running north-south, with broad intervening lowlands between the ridges. The eastern ridge exposes amygdaloidal basalt which in places is albitized and shows pillow structures, red ash, breccia, trachyte, rhyolite and green, black or brown stratified ash. Red ash breccias are lateritized at some places. On the other hand, the western ridge mainly consists of stratified, coarse-grained acid tuff, stratified yellow-brown ash, massive lava flow of andesitic composition and columnar joints. Intertrappeans on Mumbai Island, especially at Worli Hill, have high yield of many fossil animals and plants (Buist 1857; Carter 1857; Owen 1847; Williams 1953; Sukeshwala 1953).

The Salsette Island has a broad range of hills extending north-south along its center. The hills give way to tidal swamps towards the east and northwest and to a wide plain with a few hillocks towards the west. Amygdaloidal basalts occupy most of the eastern part of the island. The basalt of Gilbert Hill at Andheri has a prominent place in Mumbai geology on account of its spectacular columnar jointing. The rhyolitic flows outcrop in many areas. The basalts are intruded by sills and dykes of olivine, dolerite and trachyte. 


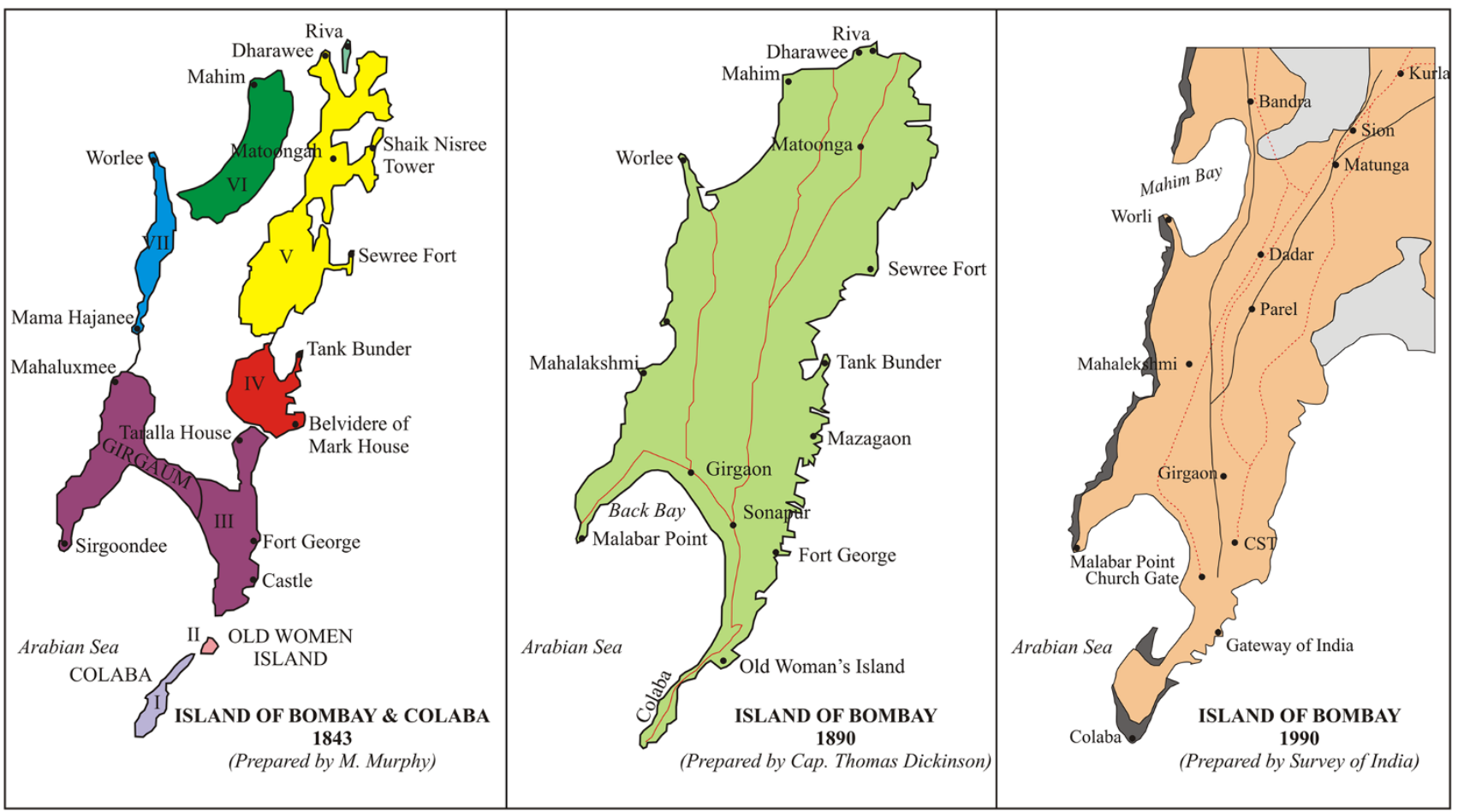

Fig. 2 Mumbai at different periods. It was created by amalgamation of seven different islands

The Trombay Island is separated from Mumbai and Salsette Island by extensive tidal flats. The Trombay Island has pahoehoe type basaltic flows with dykes of andesite and dolerite. Most of the island consists of amygdaloidal basalts and mafic pyroclastic rocks dipping $7-12^{\circ} \mathrm{W}$.

\section{Geomorphology}

The Mumbai region is characterized by considerable variation in the lithological units of the Deccan Traps. This has resulted in different degrees of resistance to natural and artificial stresses (Shah and Parthasarathy 1982). Structural features such as joints, shear zones and intrusions have also affected the morphological setup of the entire Mumbai region. These effects are clearly reflected in the coastal geomorphology and in the naturally distinct land units of the region.

The landforms present in the study area are carved out by a combination of fluvial, denudational and marine processes (Fig. 3). On the basis of different geomorphic features, the area has been divided into three distinct geomorphic land units and categorized as: (1) denudational, (2) fluvial and (3) coastal landform.

Denudational landforms are formed as a result of active processes of weathering, mass wasting and erosion due to the action of exogenic agents upon the exposed rocks. During these processes, the rocks on the land surface are worn away and the result is an overall lowering of the land surface. Cuesta, simple slope, residual hill and linear ridges are the different landforms of denudational origin. Cuestas are landforms with gentle dip slope on one side and an escarpment on other. Most of the hills of the Borivali National Park, Cumbala Hill and Malabar Hill are good examples of cuestas. Landforms with simple slope are produced by the wasting action of streams. This feature is seen in the north of the study area and in the Trombay region. Residual Hills are the end products of the process of peneplanation that reduces original mountain masses into a series of scattered knolls standing on the peneplain (Thornbury 1990). These hills are seen in north of Gorai. Linear ridges are long hills or crests of land that stretch in a straight line. Such ridges may indicate the presence of some structural control. This structural feature affects very young and transient features, offsetting streams, fans and ridge spur. In the study area, this feature occurs in Trombay and in the northern part of Borivali National Park.

Fluvial landforms in the study area are developed due to the deposition of sediments carried by streams whenever its velocity is appreciably checked. Alluvial plains, alluvial fans and deltaic plains are the different fluvial landforms seen in the study area. Alluvial plains are stream deposited features and are relatively flat areas composed of alluvium. Extensive alluvial plains are confined to the area between the seacoast and hilly regions of Borivali National Park. They have also developed around the Mumbra-Belapur 


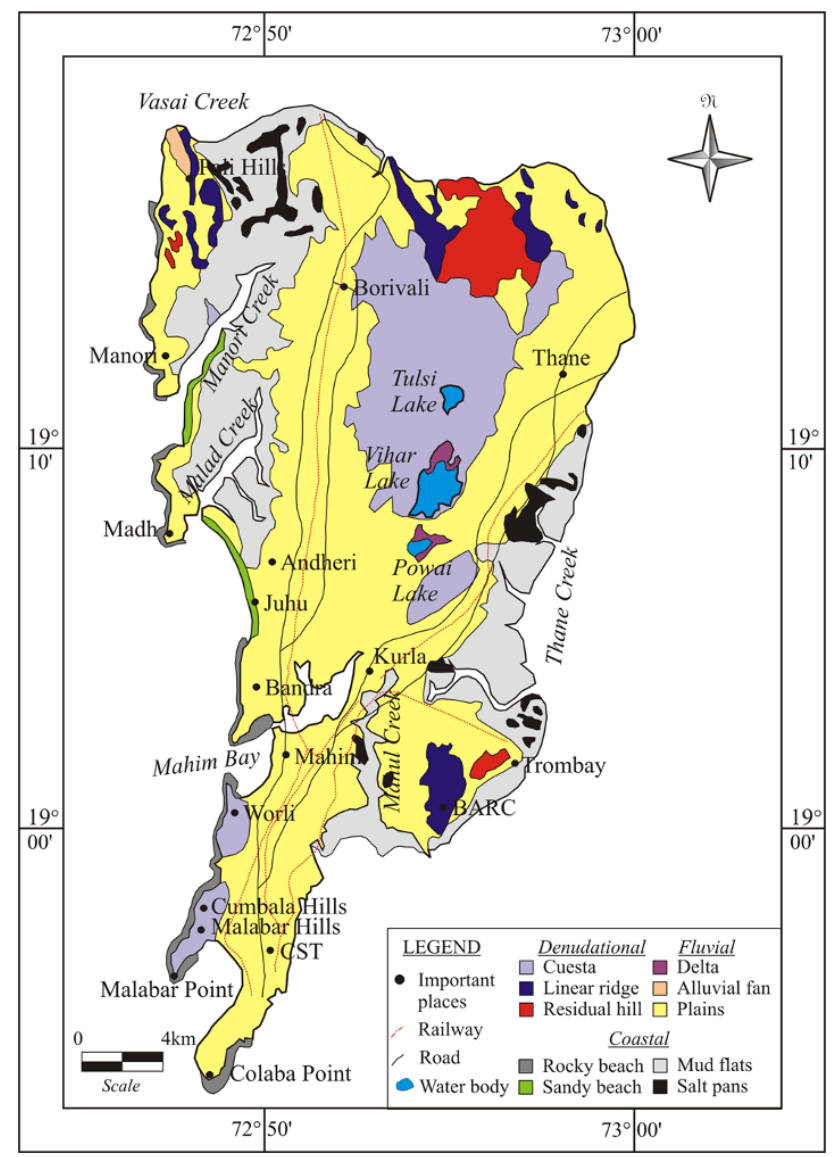

Fig. 3 Geomorphology map of Mumbai Island. The landforms are carved out by a combination of fluvial, denudational and marine processes

Hill ranges. They are formed by the deposition of the six small rivers flowing out of the Borivali National Park towards west. Minor alluvial flood plains on the east of Borivali National Park are formed as a result of material brought out by the Ulhas River and also by the numerous small streams flowing down the Ghatkopar-Thane escarpment. Alluvial fans are the result of the deposition of the materials carried by streams and are formed on foot hill regions. Sediments are deposited due to change in depth and velocity in the foothill region. Alluvial fans occur on the foothills of Pali, on the northern part of Mumbai Island and are the only location where this feature is noted. Deltaic plains are formed where streams and rivers carrying an abundant supply of sediment enter a still body of water lacking extensive wave and current scour. The flow velocity is retarded and deposition occurs. Vihar and Powai Lakes exhibit this feature. These deltas are exposed only during summer months.

Coastal landforms are produced by the action of waves and tides. Marine waters erode the rock at the shore and this continued marine erosion results in considerable modifications of shoreline. Coastal landforms are common in the study area and include mudflats, salt pans, sandy and rocky beaches. Mudflats (also known as tidal flats), are covered by permanent and/or temporary salt water, and occur in the lowland area. Twice a day, water flows in and out with the tides, filling or draining the flats. Mudflats receive nutrients from the tidal flow from the nearby marsh, particularly when the vegetation in these marshes decays. Mudflats thus have a rich plant and animal life. Mudflats are mainly seen around Thane, Manori and Malad. The widest mudflats occur around Thane Creek and support mangrove vegetation. Within the mudflats and beside the creeks, salt pans are observed. Salt pans here are artificial dry lakes that appear during summer season. They are ubiquitous in the study area and form the landforms of least relative relief. They are formed over a period of years and are found very close to coastal areas. The longer the water remains stagnant, the more concentrated minerals and salts contained in the water become. However, once the water evaporates fully, only the minerals and salts remain, forming a hard cracked surface. In the study area, it occurs in patches beside creeks. Beaches are loose unconsolidated deposits made by marine action near the shore. The lower margins of a beach are commonly beneath the waves whereas the upper margin is a few meters above the still area. Both sandy and rocky beaches are seen in the western coastal tract of the study area. Usually rocky beaches occur along the base of sea cliffs. They show a gradual change to sandy beaches. The most prominent ones are seen at Malabar hill and small patches occur along Bandra, Aksa and Gorai. Extensive sandy beaches are seen along the western shore of Mumbai, the most noticeable ones being the Worli-Bandra, Juhu, Aksa, Gorai and Utan. At Madh, large patches of rocky exposures are seen. These sandy and rocky beaches occur as linear features enclosing the land and protecting it from further marine attack.

Slope has direct control on surficial hydrologic phenomena such as runoff and infiltration. Areas with steep slope experience high runoff and less infiltration and hence there is less chance of recharge and vice versa. Contour map of the study area was categorized into five groups (Fig. 4) (Rani 2004):

- Very low $\left(<5^{\circ}\right)$ : This corresponds to flat areas typical of erosional landscapes. In the study area, most of the area is occupied by pediments.

- Low $\left(5^{\circ}-15^{\circ}\right)$ : this area is almost plain and built-up as well as agricultural land occupies large parts of this area.

- Moderate $\left(15^{\circ}-30^{\circ}\right)$ : landscape that is neither plain nor steep.

- Steep $\left(30^{\circ}-45^{\circ}\right)$ : this class can be considered to be uneconomic and requires special measures for cultivation. 


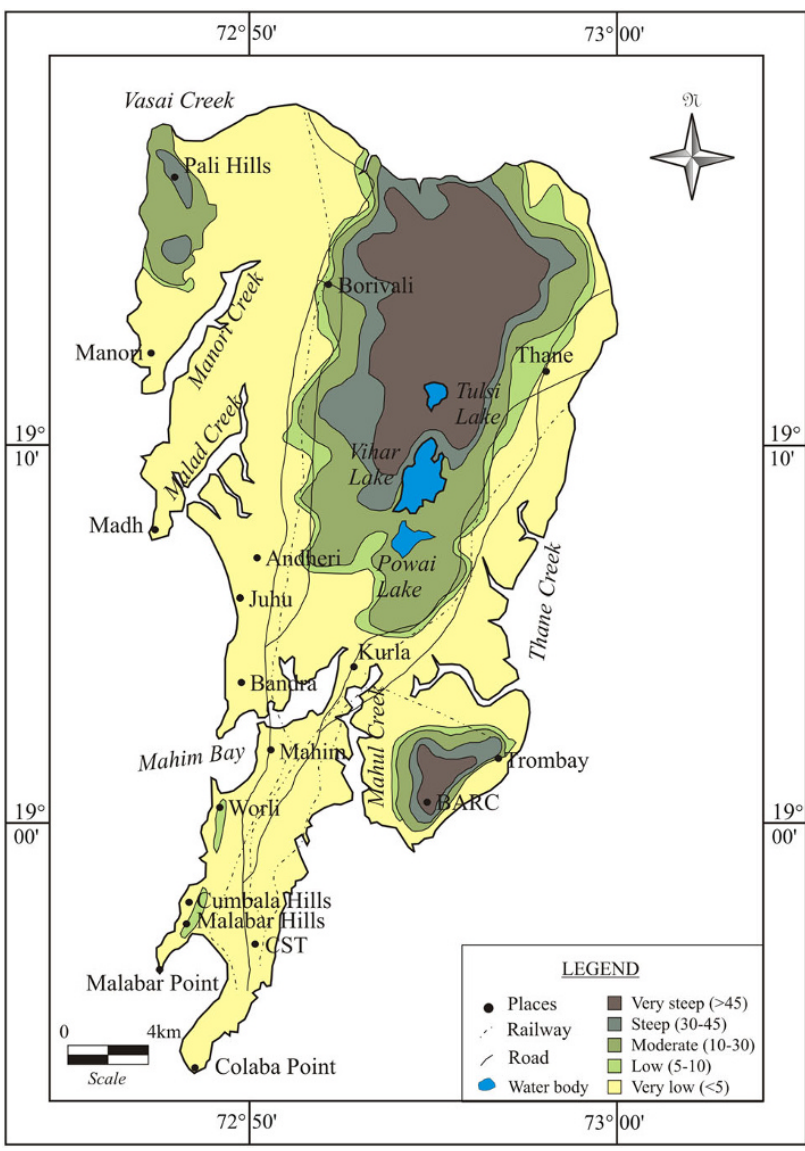

Fig. 4 Slope map of the study area. Majority of the area is under very low category. Very steep slope is seen at Pali Hills, Borivali National Park and near BARC

- Very steep $\left(>45^{\circ}\right)$ : areas which are mainly occupied by structural hills mainly escarpments.

\section{Hydrogeomorphology}

The term 'hydrogeomorphology' designates the study of landforms in relation to groundwater occurrence (Todd 1980). Hydrogeomorphic units play a vital role in identifying relative groundwater potential of different areas. Linear ridges, residual hill, cuesta and mesa are resistant landforms and groundwater prospect in these geomorphic units is poor (cf. Abiola et al. 2009). These units occur in Borivali National Park, Pali Hills, Cumbala Hills, Malabar Hills and Mumbra-Belapur Hill ranges. A linear ridge is a long hill or crest of land that stretches in a straight line whereas residual hills and mesa are isolated hills formed by differential weathering and erosion and are the end products of the process of peneplanation. Cuestas are structurally controlled hills. From the groundwater point of view, this geomorphic unit is considered as poor aquifer.
Alluvial fans are seen near foot hills and groundwater prospect in these units is moderate to good. Fluvial plains are in fact pediments developed when running water deposits material in valleys. Two types of pediments are seen like shallow and buried pediments. Shallow pediments form broad surface at the base of receding hills. Groundwater prospect in shallow pediments is moderate due to the small thickness of sediment. Buried pediments are areas where the bed rock is covered by transported fluvial overburden of considerable thickness. In the study area, shallow pediments are seen on the foothills of the Borivali Hills. Here the buried pediments occur between the shallow pediment and creek. It covers more than $75 \%$ of the area. Groundwater prospects in this unit are good (cf. Abiola et al. 2009). Wetlands/mudflats are marshy or swampy areas that are mainly made up of fine sand and silt and are covered by salt water either permanently or temporarily (Gopal 2012). Groundwater prospect is poor in terms of usability since the water is brackish. Wetlands are seen beside the creeks. The broadest of all wetlands in Mumbai occurs beside the Thane creek. Salt pans are also observed in some of these wetlands. Beach is the part of the coast that is constantly washed by waves and tides and which is covered with sediments of various sizes and compositions. In the study area, sand and rocky beaches are present along the western coast. Sediment thicknesses in these beaches are not very high. Groundwater prospect is good because of its unconsolidated nature. Due to nearness to sea, the water may be slightly salty (Mondal et al. 2010; Maiti et al. 2012).

\section{Hydrogeochemistry}

Sampling was done uniformly for the three seasons (premonsoon, monsoon and post-monsoon; Tables 1, 2, 3, respectively) from both dug and open wells covering all the geomorphic landforms, viz., denudational, fluvial and coastal. The sample locations are shown in Fig. 5 and described vis-à-vis with the landforms Table 4. The maximum number of samples was collected from fluvial landforms because apart from the aim of establishing the role of fluvial landforms as a recharge zone, the study also aims at understanding the quality of the groundwater within this unit, as this landform forms the main feeder for the domestic use of groundwater.

Groundwater condition in denudational landforms

Groundwater samples collected from denudational landforms have Total Dissolved Solids (TDS; includes bicarbonates, sulfates and chlorides of calcium, magnesium and sodium) values $<1,000 \mathrm{mg} / \mathrm{l}$ (except 3 samples). As per 
Table 1 Chemical analysis data for major ions: pre-monsoon 2012

\begin{tabular}{|c|c|c|c|c|c|c|c|c|c|c|c|c|c|}
\hline $\begin{array}{l}\text { Sample } \\
\text { No. }\end{array}$ & $\mathrm{pH}$ & $\begin{array}{l}\text { Temperature } \\
\left({ }^{\circ} \mathrm{C}\right)\end{array}$ & $\begin{array}{l}\mathrm{EC}(\mu \mathrm{s} / \\
\mathrm{cm})\end{array}$ & $\begin{array}{l}\text { TDS } \\
(\mathrm{ppm})\end{array}$ & $\begin{array}{l}\text { TH } \\
\text { (ppm) }\end{array}$ & $\begin{array}{l}\mathrm{Na}^{+} \\
(\mathrm{ppm})\end{array}$ & $\begin{array}{l}\mathrm{K}^{+} \\
(\mathrm{ppm})\end{array}$ & $\begin{array}{l}\mathrm{Ca}^{2+} \\
(\mathrm{ppm})\end{array}$ & $\begin{array}{l}\mathrm{Mg}^{2+} \\
(\mathrm{ppm})\end{array}$ & $\begin{array}{l}\mathrm{Cl}^{-} \\
(\mathrm{ppm})\end{array}$ & $\begin{array}{l}\mathrm{SO}_{4}^{2-} \\
(\mathrm{ppm})\end{array}$ & $\begin{array}{l}\mathrm{CO}_{3}^{2-} \\
(\mathrm{ppm})\end{array}$ & $\begin{array}{l}\mathrm{HCO}_{3}- \\
(\mathrm{ppm})\end{array}$ \\
\hline 1 & 8.3 & 29 & 1,343 & 860 & 277 & 170 & 15 & 63.5 & 29 & 211 & 46.3 & 30 & 295 \\
\hline 2 & 8.5 & 31 & 447 & 286 & 139 & 11 & 14 & 31.7 & 14 & 57 & 9.6 & 20 & 120 \\
\hline 3 & 8.7 & 30.5 & 648 & 415 & 158 & 90 & 7 & 31.7 & 19 & 110 & 30.1 & 0 & 120 \\
\hline 4 & 8.8 & 29.5 & 492 & 315 & 158 & 33 & 15 & 55.6 & 5 & 57 & 33.7 & 20 & 125 \\
\hline 5 & 8.8 & 30 & 1,937 & 1,240 & 257 & 275 & 28 & 95.2 & 5 & 575 & 98.4 & 80 & 440 \\
\hline 6 & 9 & 29.5 & 1,143 & 732 & 336 & 135 & 50 & 55.6 & 48 & 101 & 2.6 & 40 & 375 \\
\hline 7 & 8.2 & 30 & 1,571 & 1,005 & 435 & 175 & 13 & 79.4 & 58 & 187 & 150.2 & 20 & 410 \\
\hline 8 & 8.9 & 30 & & 0 & 515 & 245 & 45 & 198 & 5 & 440 & 54.5 & 50 & 390 \\
\hline 9 & 8.2 & & 813 & 520 & 237 & 115 & 2.5 & 39.7 & 34 & 34 & 41.8 & 40 & 310 \\
\hline 10 & 8.7 & 30 & 1,111 & 711 & 396 & 90 & 45 & 111 & 29 & 115 & 75.8 & 40 & 200 \\
\hline 11 & 8.6 & 30 & 1,292 & 827 & 237 & 21.5 & 70 & 31.7 & 39 & 144 & 53 & 50 & 345 \\
\hline 12 & 8.7 & 30 & 1,286 & 823 & 317 & 150 & 55 & 87.3 & 24 & 191 & 63.5 & 0 & 215 \\
\hline \multicolumn{14}{|l|}{13} \\
\hline 14 & 8.2 & 32 & 695 & 445 & 277 & 35.5 & 11 & 63.5 & 29 & 57 & 62.9 & 40 & 185 \\
\hline 15 & 8.4 & 28 & 608 & 389 & 238 & 34 & 7 & 55.6 & 24 & 53 & 46.1 & 60 & 180 \\
\hline 16 & 8.5 & 30 & 743 & 476 & 238 & 90 & 4.5 & 63.5 & 19 & 86 & 38.7 & 20 & 235 \\
\hline 17 & 8.9 & 31 & 701 & 119 & 277 & 35.5 & 6 & 87.3 & 14 & 81 & 45.9 & 40 & 195 \\
\hline 18 & 8.4 & 31 & 368 & 236 & 158 & 21.5 & 5 & 397 & 14 & 38 & 11.8 & 0 & 140 \\
\hline 19 & 9 & 29 & 851 & 545 & 337 & 75 & 9.5 & 87.3 & 29 & 101 & 29.1 & 60 & 225 \\
\hline 20 & 8.4 & 29 & 500 & 320 & 218 & 30.5 & 2.5 & 55.6 & 19 & 53 & 35.5 & 20 & 160 \\
\hline 21 & 8.8 & 30.5 & 623 & 399 & 297 & 27.5 & 3.5 & 63.5 & 34 & 62 & 32.3 & 30 & 190 \\
\hline \multicolumn{14}{|l|}{22} \\
\hline 23 & 8.7 & 29 & 416 & 266 & 158 & 130 & 6 & 55.6 & 5 & 86 & 3.2 & 0 & 160 \\
\hline 24 & 8.7 & 29 & 1,255 & 803 & 237 & 160 & 100 & 31.7 & 39 & 163 & 37.7 & 30 & 420 \\
\hline \multicolumn{14}{|l|}{25} \\
\hline 26 & 8.9 & 29 & 513 & 328 & 257 & 22 & 5.5 & 95.2 & 5 & 43 & 35.3 & 30 & 190 \\
\hline 27 & 8.1 & 29 & 564 & 361 & 238 & 31 & 9 & 63.5 & 19 & 48 & 12.9 & 30 & 210 \\
\hline 28 & 8.1 & 30 & 971 & 621 & 356 & 35 & 10 & 55.6 & 53 & 115 & 44.4 & 0 & 280 \\
\hline 29 & 8.2 & 29 & 580 & 371 & 178 & 33 & 15 & 47.6 & 14 & 62 & 56.3 & 50 & 255 \\
\hline 30 & 8.6 & 29 & 813 & 520 & 238 & 95 & 27 & 79.4 & 10 & 67 & 20.9 & 20 & 305 \\
\hline 31 & 8 & 29.5 & 1,161 & 743 & 455 & 70 & 2 & 119 & 38 & 278 & 35.7 & 0 & 135 \\
\hline \multicolumn{14}{|l|}{32} \\
\hline 33 & 8.3 & 32 & 367 & 235 & 178 & 22.5 & 3 & 63.5 & 5 & 38 & 162.1 & 0 & 145 \\
\hline 34 & 8.7 & 31 & 706 & 452 & 257 & 30 & 8 & 63.5 & 24 & 45 & 27.8 & 60 & 165 \\
\hline 35 & 8.4 & 34 & 148 & 947 & 79 & 8 & 2.5 & 23.8 & 5 & 11 & 6.3 & 0 & 55 \\
\hline 36 & 8.8 & 30 & 378 & 242 & 237 & 15 & 0.5 & 39.7 & 34 & 11 & 14 & 50 & 115 \\
\hline 37 & 8.2 & 30 & 548 & 351 & 297 & 14 & 0.5 & 71.4 & 29 & 17 & 30.5 & 0 & 215 \\
\hline 38 & 8.2 & 28.5 & 1,003 & 642 & 495 & 23.5 & 0.5 & 111 & 53 & 56 & 177.2 & 0 & 105 \\
\hline \multicolumn{14}{|l|}{39} \\
\hline \multicolumn{14}{|l|}{40} \\
\hline 41 & 8.7 & 30 & 761 & 487 & 297 & 70 & 9 & 71.4 & 29 & 45 & 46.5 & 0 & 270 \\
\hline 42 & 7.9 & 29 & 1,074 & 687 & 376 & 75 & 21 & 111 & 24 & 56 & 63.5 & 0 & 365 \\
\hline 43 & 7.9 & 29.5 & 875 & 560 & 297 & 75 & 3 & 63.5 & 34 & 56 & 51.4 & 50 & 225 \\
\hline 44 & 8.3 & 29 & 909 & 582 & 297 & 80 & 1.5 & 63.5 & 34 & 56 & 24.6 & 10 & 175 \\
\hline 45 & 8.4 & 29 & 533 & 341 & 198 & 30 & 4 & 55.6 & 14 & 28 & 29 & 50 & 120 \\
\hline 46 & 8.5 & 29 & 604 & 387 & 238 & 33.5 & 3 & 71.4 & 14 & 22 & 59.1 & 0 & 210 \\
\hline 47 & 8.2 & 30 & & 0 & 574 & 270 & 5.5 & 119 & 67 & 258 & 91.2 & 0 & 230 \\
\hline
\end{tabular}


Table 1 continued

\begin{tabular}{|c|c|c|c|c|c|c|c|c|c|c|c|c|c|}
\hline $\begin{array}{l}\text { Sample } \\
\text { No. }\end{array}$ & $\mathrm{pH}$ & $\begin{array}{l}\text { Temperature } \\
\left({ }^{\circ} \mathrm{c}\right)\end{array}$ & $\begin{array}{l}\mathrm{EC}(\mu \mathrm{s} / \\
\mathrm{cm})\end{array}$ & $\begin{array}{l}\text { TDS } \\
(\mathrm{ppm})\end{array}$ & $\begin{array}{l}\text { TH } \\
(\mathrm{ppm})\end{array}$ & $\begin{array}{l}\mathrm{Na}^{+} \\
(\mathrm{ppm})\end{array}$ & $\begin{array}{l}\mathrm{K}^{+} \\
(\mathrm{ppm})\end{array}$ & $\begin{array}{l}\mathrm{Ca}^{2+} \\
(\mathrm{ppm})\end{array}$ & $\begin{array}{l}\mathrm{Mg}^{2+} \\
(\mathrm{ppm})\end{array}$ & $\begin{array}{l}\mathrm{Cl}^{-} \\
(\mathrm{ppm})\end{array}$ & $\begin{array}{l}\mathrm{SO}_{4}^{2-} \\
(\mathrm{ppm})\end{array}$ & $\begin{array}{l}\mathrm{CO}_{3}{ }^{2-} \\
(\mathrm{ppm})\end{array}$ & $\begin{array}{l}\mathrm{HCO}_{3}{ }^{-} \\
(\mathrm{ppm})\end{array}$ \\
\hline 48 & & & 277 & 177 & 158 & 20 & 1.5 & 31.7 & 19 & 22 & 30.2 & 0 & 95 \\
\hline 49 & 8.2 & 29.5 & 1,086 & 695 & 416 & 90 & 3 & 95.2 & 43 & 50 & 158.4 & 0 & 370 \\
\hline 50 & 8.7 & 31 & 349 & 223 & 198 & 250 & 11 & 47.6 & 19 & 207 & 13 & 50 & 270 \\
\hline 51 & 8.5 & 29 & & 0 & 317 & 16 & 0.5 & 47.6 & 48 & 22 & 99.2 & 0 & 125 \\
\hline 52 & 8.2 & 32 & 1,219 & 780 & 297 & 140 & 55 & 63.5 & 34 & 50 & 36.6 & 0 & 485 \\
\hline 53 & 8 & 29 & 604 & 387 & 257 & 28 & 1 & 55.6 & 29 & 50 & 45 & 0 & 205 \\
\hline 54 & 8.1 & 30 & 1,337 & 856 & 317 & 160 & 4.5 & 119 & 5 & 118 & 52.6 & 0 & 80 \\
\hline \multicolumn{14}{|l|}{55} \\
\hline 56 & 9 & 30 & 585 & 374 & 317 & 20 & 0 & 71.4 & 34 & 22 & 50.5 & 40 & 165 \\
\hline 57 & 8.7 & 29 & 478 & 306 & 178 & 36 & 2.5 & 23.8 & 29 & 22 & 16.1 & 20 & 200 \\
\hline 58 & 8.8 & 29 & 635 & 406 & 257 & 70 & 1.5 & 63.5 & 24 & 22 & 22.7 & 30 & 185 \\
\hline
\end{tabular}

Carroll's (1962) classification, the water in this landform is of 'fresh' type. Total Hardness (TH; 2.497 $\mathrm{Ca}^{2+}+4.11 \mathrm{Mg}^{2+}$ ) has a value $<300 \mathrm{ppm}$ (except 10 samples) falling in the category of 'soft' and 'hard' when compared to the 'very hard' category in other landforms. $\mathrm{Na}^{+}$and $\mathrm{K}^{+}$are usually less in this landform and this indicates that it is a poor recharge zone. In a basaltic terrain $\mathrm{Ca}^{2+}$ and $\mathrm{Mg}^{2+}$ will be more as these are derived from ferromagnesian minerals which are usual components of any basic/ultrabasic rock and in this terrain $\mathrm{Ca}^{2+}$ and $\mathrm{Mg}^{2+}$ values of 64.6 and $19.8 \mathrm{ppm}$, respectively, have been reported (Rani 2004). But irrespective of this basaltic terrain, groundwater in these landforms shows a smaller value for $\mathrm{Ca}^{2+}$ and $\mathrm{Mg}^{2+}$. The $\mathrm{Cl}^{-}$and $\mathrm{SO}_{4}{ }^{2-}$ anionic species content in the groundwater of basaltic region is 49 and $40.5 \mathrm{ppm}$, respectively (Rani 2004). $\mathrm{Cl}^{-}$increases in groundwater where there is sea water incursion as well as where salt panning is active and $\mathrm{SO}_{4}{ }^{2-}$ increases in areas where anthropogenic activities prevail. The values of $\mathrm{Cl}^{-}$ and $\mathrm{SO}_{4}{ }^{2-}$ for the three seasons do not show any particular trend and this is indicative of the low infiltration during monsoon. Alkalinity $\left(\mathrm{CO}_{3}{ }^{2-}\right.$ and $\left.\mathrm{HCO}_{3}{ }^{-}\right)$is less in the study area and is usually contributed by calcite occurring as secondary fillings in vesicles and vugs. The hydrogeochemistry of these landforms reveals that the quality of water is good, but replenishment during monsoon is very small.

\section{Groundwater condition in fluvial landforms}

Majority of the samples were collected from these landforms. During monsoon, $\mathrm{pH}$ decreases due to dilution of groundwater by the high influx of meteoritic water in fluvial landforms. Similar is the case with temperature and electrical conductivity. In contrast TDS value increases during monsoon. In these landforms, in general, cationic and anionic species do not show any specific trend when comparing among the pre-monsoon, monsoon and postmonsoon data. But $\mathrm{Ca}^{2+}, \mathrm{Cl}^{-}, \mathrm{SO}_{4}{ }^{2-}, \mathrm{CO}_{3}{ }^{2-}$ and $\mathrm{HCO}_{3}{ }^{-}$ show an enhanced value during monsoon. Increase in $\mathrm{Ca}^{2+}$ is attributed to the rock-water interaction during the latter's underground sojourn and increase in $\mathrm{Cl}^{-}$is due to the salt panning activity. Huge laundry business and its associated detergent residue result in the increase of $\mathrm{SO}_{4}{ }^{2-}$ in these landforms. $\mathrm{CO}_{3}{ }^{2-}$ and $\mathrm{HCO}_{3}{ }^{-}$are derived from the residue left in the soil after evaporation during the hot summer season. These landforms have good potential to hold water. The quality of water is usually good, but in a highly urbanized city like Mumbai, every pocket of groundwater will be adversely affected if proper management is not adopted.

Groundwater condition in coastal landforms

Groundwater in these landforms is characterized by high electrical conductivity because of increase in $\mathrm{Na}^{+}$and $\mathrm{Cl}^{-}$. This shows that these landforms are frequently in contact with marine water. TDS values of only a few water samples have values $>1,000 \mathrm{mg} / \mathrm{l}$ indicating a 'brackish' type. TDS usually increases from pre-monsoon to monsoon to postmonsoon. TH values are above 300 ppm belonging to "very hard' category during monsoon season whereas it remains in 'hard' category in the other parts of the year. $\mathrm{Ca}^{2+}$ and $\mathrm{Mg}^{2+}$ are usually low during pre-monsoon whereas it increases subsequently with the progress of the monsoon season. The amount of $\mathrm{Na}^{+}$is more in groundwater of these landforms and this ion enters the groundwater mainly by sea water incursion. $\mathrm{K}^{+}$is comparatively less in the study area because of the paucity of potash minerals in the host rocks. $\mathrm{Cl}^{-}$is more in this area and it is also due to marine water invasion. It usually decreases during monsoon due to dilution by meteoritic water. $\mathrm{SO}_{4}{ }^{2-}$ has a 
Table 2 Chemical analysis data for major ions: monsoon 2012

\begin{tabular}{|c|c|c|c|c|c|c|c|c|c|c|c|c|c|}
\hline $\begin{array}{l}\text { Sample } \\
\text { No. }\end{array}$ & $\mathrm{pH}$ & $\begin{array}{l}\text { Temperature } \\
\left({ }^{\circ} \mathrm{c}\right)\end{array}$ & $\begin{array}{l}\mathrm{EC}(\mu \mathrm{s} / \\
\mathrm{cm})\end{array}$ & $\begin{array}{l}\text { TDS } \\
\text { (ppm) }\end{array}$ & $\begin{array}{l}\mathrm{TH} \\
(\mathrm{ppm})\end{array}$ & $\begin{array}{l}\mathrm{Na}^{+} \\
(\mathrm{ppm})\end{array}$ & $\begin{array}{l}\mathrm{K}^{+} \\
(\mathrm{ppm})\end{array}$ & $\begin{array}{l}\mathrm{Ca}^{2+} \\
(\mathrm{ppm})\end{array}$ & $\begin{array}{l}\mathrm{Mg}^{2+} \\
(\mathrm{ppm})\end{array}$ & $\begin{array}{l}\mathrm{Cl}^{-} \\
(\mathrm{ppm})\end{array}$ & $\begin{array}{l}\mathrm{SO}_{4}^{2-} \\
(\mathrm{ppm})\end{array}$ & $\begin{array}{l}\mathrm{CO}_{3}^{2-} \\
(\mathrm{ppm})\end{array}$ & $\begin{array}{l}\mathrm{HCO}_{3}{ }^{-}( \\
\mathrm{ppm})\end{array}$ \\
\hline 1 & 7.4 & 28 & 1,009 & 646 & 416 & 148 & 18 & 143 & 14.4 & 130.2 & 69.4 & 0 & 354 \\
\hline 2 & 7.2 & 28 & 1,003 & 642 & 336 & 130 & 25 & 63.5 & 43.3 & 120.5 & 77.3 & 0 & 306.8 \\
\hline 3 & 6.8 & 28 & 455 & 291 & 178 & 65 & 7.4 & 63.5 & 43.3 & 1,205 & 77.3 & 0 & 306.8 \\
\hline 4 & 7.4 & 28 & 729 & 467 & 238 & 126 & 18 & 63.5 & 19.2 & 72.3 & 54.8 & 0 & 259.6 \\
\hline 5 & 7.8 & 29 & 1,974 & 1,263 & 317 & 485 & 44 & 63.5 & 38.5 & 303.7 & 126.5 & 47.2 & 483.8 \\
\hline 6 & 7.8 & 28 & 1,000 & 640 & 257 & 102 & 44 & 55.6 & 28.8 & 77.1 & 60.2 & 0 & 413 \\
\hline 7 & 7.4 & 28 & 1,031 & 660 & 356 & 180 & 17 & 95.2 & 28.8 & 110.9 & 75.1 & 0 & 436.6 \\
\hline 8 & 7.6 & 28 & 1,642 & 1,051 & 396 & 210 & 42 & 95.2 & 38.4 & 270 & 100.5 & 0 & 342.2 \\
\hline 9 & 7.7 & 28 & 897 & 574 & 297 & 148 & 2 & 63.5 & 33.7 & 77.1 & 78.2 & 0 & 401.2 \\
\hline 10 & 7.5 & 28 & 1,004 & 643 & 475 & 94 & 32 & 143 & 28.8 & 82 & 72.8 & 0 & 377.6 \\
\hline 11 & 7.6 & 28 & 1,355 & 867 & 435 & 148 & 88 & 103 & 43.3 & 139.8 & 61 & 0 & 542.8 \\
\hline 12 & 7.4 & 28 & 1,233 & 789 & 396 & 110 & 58 & 119 & 24 & 110.9 & 90.6 & 0 & 295 \\
\hline 13 & 7.5 & 28 & 836 & 535 & 317 & 106 & 4.6 & 87.3 & 24 & 82 & 39.6 & 0 & 401.2 \\
\hline 14 & 7.5 & 25 & 1,141 & 730 & 376 & 126 & 30 & 119 & 19.2 & 135 & 55.3 & 0 & 330.4 \\
\hline 15 & 7.5 & 28 & 962 & 616 & 416 & 88 & 8.6 & 127 & 24 & 96.4 & 56.7 & 0 & 318.6 \\
\hline 16 & 7.4 & 27 & 654 & 419 & 277 & 72 & 6.2 & 63.5 & 28.8 & 67.5 & 37.3 & 0 & 306.8 \\
\hline 17 & 7.2 & 28 & 513 & 328 & 238 & 24.6 & 4.4 & 71.4 & 14.4 & 38.6 & 19.9 & 0 & 271.4 \\
\hline 18 & 7.2 & 28 & 472 & 302 & 178 & 27.4 & 4.1 & 47.6 & 14.4 & 48.2 & 30.7 & 0 & 188.8 \\
\hline 19 & 7.3 & 28 & 923 & 591 & 356 & 78 & 12 & 95.2 & 28.8 & 110.9 & 21.8 & 0 & 389.4 \\
\hline 20 & 7.4 & 28.5 & 601 & 385 & 257 & 54 & 6 & 55.6 & 28.8 & 72.3 & 25.4 & 0 & 259.6 \\
\hline 21 & 7.3 & 28 & 452 & 289 & 238 & 19.2 & 1.6 & 63.5 & 19.2 & 33.7 & 35.2 & 0 & 212.4 \\
\hline 22 & 7.1 & 27 & 796 & 509 & 317 & 76 & 8.2 & 79.4 & 28.8 & 62.7 & 52.6 & 0 & 342.2 \\
\hline 23 & 7.8 & 28 & 499 & 319 & 198 & 25.8 & 21 & 47.6 & 19.2 & 38.6 & 17.9 & 0 & 271.4 \\
\hline 24 & 7.7 & 28 & 1,247 & 798 & 336 & 134 & 86 & 71.4 & 38.5 & 135 & 76.3 & 0 & 495.6 \\
\hline 25 & 7.8 & 27 & 773 & 495 & 257 & 98 & 47 & 63.5 & 24 & 67.5 & 58.3 & 0 & 330.4 \\
\hline 26 & 7.6 & 28 & 589 & 377 & 277 & 27.2 & 7.4 & 95.2 & 9.6 & 38.6 & 40.4 & 0 & 283.2 \\
\hline 27 & 7.2 & 28 & 785 & 502 & 396 & 58 & 13 & 135 & 14.4 & 86.8 & 73.5 & 0 & 295 \\
\hline 28 & 7.2 & 28 & 1,725 & 1,104 & 673 & 102 & 20 & 143 & 76.9 & 250.7 & 165.3 & 0 & 424.8 \\
\hline 29 & 7.2 & 29 & 622 & 398 & 337 & 40 & 14 & 111 & 14.4 & 48.2 & 50.1 & 0 & 354 \\
\hline 30 & 7.6 & 28 & 635 & 406 & 238 & 131 & 21 & 71.4 & 14.4 & 53 & 45 & 0 & 354 \\
\hline 31 & 7.6 & 28 & 687 & 440 & 257 & 5.8 & 12 & 71.4 & 19.2 & 62.7 & 54.1 & 0 & 259.6 \\
\hline 32 & 7.4 & 28 & 541 & 346 & 198 & 42 & 2.6 & 55.6 & 14.4 & 91.6 & 31.4 & 0 & 94.4 \\
\hline 33 & 7.7 & 28 & 353 & 226 & 158 & 23.2 & 1.8 & 47.6 & 9.6 & 24.1 & 37.5 & 0 & 271.4 \\
\hline 34 & 7.4 & 28 & 764 & 489 & 317 & 72 & 4.4 & 95.2 & 19.2 & 163.9 & 49.8 & 0 & 200.6 \\
\hline 35 & 7.2 & 28 & 311 & 199 & 158 & 12.6 & 0.8 & 31.7 & 19.2 & 33.7 & 41 & 0 & 94.4 \\
\hline 36 & 7.5 & 28 & 641 & 410 & 317 & 26.8 & 2.6 & 87.3 & 24 & 72.3 & 58.3 & 0 & 224.2 \\
\hline 37 & 7.6 & 28 & 325 & 208 & 178 & 12.7 & 0.1 & 39.7 & 19.2 & 19.3 & 28.4 & 0 & 177 \\
\hline 38 & 7.1 & 28 & & & 455 & 21 & 0.3 & 95.2 & 52.9 & 57.9 & 72.2 & 0 & 295 \\
\hline 39 & 6.8 & 28 & 752 & 481 & 336 & 21 & 0.2 & 79.4 & 33.6 & 101.2 & 116.7 & 0 & 153.4 \\
\hline 40 & 7.1 & 28 & 735 & 470 & 158 & 20.9 & 5.8 & 39.7 & 14.4 & 38.6 & 16.2 & 0 & 165.2 \\
\hline 41 & 6.8 & 28 & 791 & 506 & 336 & 118 & 13 & 79.4 & 33.6 & 106.1 & 147 & 0 & 141.6 \\
\hline 42 & 7.2 & 29 & 944 & 604 & 297 & 96 & 7.8 & 87.3 & 19.2 & 62.7 & 79.5 & 0 & 295 \\
\hline 43 & 7.2 & 28 & 783 & 501 & 436 & 152 & 5.2 & 127 & 28.8 & 106.1 & 211.3 & 0 & 283.2 \\
\hline 44 & 7.2 & 28 & 1,237 & 792 & 376 & 106 & 1.8 & 71.4 & 48.1 & 110.9 & 99.3 & 0 & 165.2 \\
\hline 45 & 7.1 & 28 & 913 & 584 & 139 & 24 & 4.1 & 47.6 & 4.8 & 28.9 & 56.3 & 0 & 377.6 \\
\hline 46 & 7.4 & 28 & 646 & 415 & 336 & 84 & 4.7 & 79.4 & 33.6 & 48.2 & 97.7 & 0 & 47.2 \\
\hline 47 & 7.4 & 28 & 928 & 594 & 376 & 117 & 1.6 & 87.3 & 38.5 & 144.6 & 86 & 0 & 318.6 \\
\hline
\end{tabular}


Table 2 continued

\begin{tabular}{|c|c|c|c|c|c|c|c|c|c|c|c|c|c|}
\hline $\begin{array}{l}\text { Sample } \\
\text { No. }\end{array}$ & $\mathrm{pH}$ & $\begin{array}{l}\text { Temperature } \\
\left({ }^{\circ} \mathrm{c}\right)\end{array}$ & $\begin{array}{l}\mathrm{EC}(\mu \mathrm{s} / \\
\mathrm{cm})\end{array}$ & $\begin{array}{l}\text { TDS } \\
(\mathrm{ppm})\end{array}$ & $\begin{array}{l}\text { TH } \\
(\mathrm{ppm})\end{array}$ & $\begin{array}{l}\mathrm{Na}^{+} \\
(\mathrm{ppm})\end{array}$ & $\begin{array}{l}\mathrm{K}^{+} \\
(\mathrm{ppm})\end{array}$ & $\begin{array}{l}\mathrm{Ca}^{2+} \\
(\mathrm{ppm})\end{array}$ & $\begin{array}{l}\mathrm{Mg}^{2+} \\
(\mathrm{ppm})\end{array}$ & $\begin{array}{l}\mathrm{Cl}^{-} \\
(\mathrm{ppm})\end{array}$ & $\begin{array}{l}\mathrm{SO}_{4}^{2-} \\
(\mathrm{ppm})\end{array}$ & $\begin{array}{l}\mathrm{CO}_{3}{ }^{2-} \\
(\mathrm{ppm})\end{array}$ & $\begin{array}{l}\mathrm{HCO}_{3}{ }^{-}( \\
\mathrm{ppm})\end{array}$ \\
\hline 48 & 7.2 & 28 & 233 & 149 & 83.4 & 18.4 & 0.3 & 31.7 & 9.6 & 14.5 & 41.6 & 0 & 106.2 \\
\hline 49 & 7.2 & 28 & 1,357 & 869 & 524 & 136 & 5.3 & 206 & 43.2 & 101.2 & 334.8 & 0 & 483.8 \\
\hline 50 & & & 349 & 223 & 178 & 9.6 & 1 & 39.7 & 19.2 & 28.9 & 27.4 & 0 & 165.2 \\
\hline 51 & 7.4 & 28 & 1,826 & 1,169 & 416 & 258 & 10 & 111 & 33.6 & 351.9 & 35.5 & 0 & 354 \\
\hline 52 & 7.4 & 28 & 1,380 & 883 & 416 & 148 & 4.4 & 135 & 19.2 & 173.6 & 69.5 & 0 & 401.2 \\
\hline 53 & 7.3 & 28 & 297 & 190 & 139 & 18.4 & 1 & 31.7 & 14.4 & 24.1 & 22.7 & 0 & 129.8 \\
\hline 54 & 7.4 & 29 & 571 & 365 & 297 & 25.6 & 3 & 79.4 & 24 & 82 & 55.9 & 0 & 177 \\
\hline 55 & & & 640 & 410 & 396 & 26.4 & 1 & 95.2 & 38.4 & 101.2 & 20.4 & 0 & 295 \\
\hline 56 & 7.6 & 28 & 533 & 341 & 297 & 17.2 & 0 & 63.5 & 33.7 & 43.4 & 45.1 & 0 & 236 \\
\hline 57 & 7.2 & 28 & 371 & 237 & 257 & 20.6 & 4 & 71.4 & 19.2 & 38.6 & 31.7 & 0 & 236 \\
\hline 58 & 7.2 & 28 & 554 & 355 & 178 & 72 & 4 & 55.6 & 9.6 & 43.4 & 35.5 & 0 & 236 \\
\hline
\end{tabular}

slightly higher value in this landform when compared to the groundwater of typical basaltic region where its content will be around $40.5 \mathrm{ppm}$. These landforms are good in recharging the aquifer, but due to repeated marine incursion the quality always is questionable.

\section{Validation through borehole data}

Basaltic lava flow shows contrasting water-bearing properties in the different units constituting them. A study of subsurface geology of Mumbai Island reveals that the area has a multi-layered aquifer system comprising aquicludes of basalt and aquifers of vesicular and fractured/jointed zones (Cook 2003). Shallow aquifers are made up of weathered, jointed and fractured zones (Agashe 1989). These aquifers form an important source of water supply for domestic, agricultural and industrial needs.

Groundwater occurs under water table conditions in both the weathered jointed zones of massive and vesicular units. These units show both lateral and vertical variations in the degree of weathering and porosity. The primary porosity of Deccan basalts is very low. The secondary features developed in it due to spheroidal weathering, jointing, fracturing and fissuring, thereby enhancing the porosity of the rocks and thereby increasing the storativity and transmissivity of basaltic rocks. But in the case of intertrappeans and tuffaceous rocks, weathering decreases the groundwater yield capacity. The extent of yield capacity of different rock units also depends upon the topography.

Borehole data provide reliable information about the subsurface lithology, extent of weathering and thickness of subsurface layers. The litholog data of about 108 bore wells (Fig. 5; of the 108 only 10 are shown in the figure) of the study area were prepared and studied. These lithologs provide data about the subsurface lithology up to a depth of $85 \mathrm{~m}$. Based on the lithologs, the subsurface layers can be broadly classified into three categories.

(1) Shallow depth aquifer: extends up to a depth of $20 \mathrm{~m}$ bgl (below ground level) and mainly consists of top soil and weathered rock.

(2) Medium depth aquifer: extends from 20 to $60 \mathrm{~m} \mathrm{bgl}$.

(3) Deep aquifer: occurring beneath $65 \mathrm{~m} \mathrm{bgl}$.

In most borewells, the top soil is brownish gray to black in color with weathered rock debris and varies in thickness from 2 to $13 \mathrm{~m}$. This forms the shallow depth aquifer. Mainly two types of basalt-massive basalt and the vesicular amygdaloidal basalt that constitute the medium depth aquifer underlie this zone. The thickness of the layer varies from 10 to $40 \mathrm{~m}$. In some locations, the medium depth aquifer, i.e., the zone beneath the weathered rock consists of trachyte, rhyolite or tuff. The nature of the lithology of medium depth aquifer varies from one location to another.

In the Churchgate area, lenses of sand are seen. While comparing the boreholes in the southern part of Mumbai it is very evident that the discharge mainly depends upon the thickness of the weathered material. It varies from 2,000 to 4,000 1/hr in southern Mumbai. In the Cumbala Hill pyroclastics occur beneath the massive basalt. In Worli-Juhu area also pyroclastics form the medium aquifer, but here it occurs just beneath the weathered rock unlike Cumbala Hill where it occurs beneath the massive basalt. The pyroclastics usually have low discharge values, but permeability is varied when fractures and red boles are present. In Vikhroli-Powai area, pyroclastics as well as massive basalt occur as the medium depth aquifer. Tuffaceous rocks act as medium depth aquifers at Parel, Sion and Ghodbhander area. Around Matunga and Parel, pillow lavas mainly dominate the medium depth aquifer. Near Akse, Madh, 
Table 3 Chemical analysis data for major ions: post-monsoon 2013

\begin{tabular}{|c|c|c|c|c|c|c|c|c|c|c|c|c|c|}
\hline $\begin{array}{l}\text { Sample } \\
\text { No }\end{array}$ & $\mathrm{pH}$ & $\begin{array}{l}\text { Temperature } \\
\left({ }^{\circ} \mathrm{c}\right)\end{array}$ & $\begin{array}{l}\mathrm{EC}(\mu \mathrm{s} / \\
\mathrm{cm})\end{array}$ & $\begin{array}{l}\text { TDS } \\
(\mathrm{ppm})\end{array}$ & $\begin{array}{l}\text { TH } \\
(\mathrm{ppm})\end{array}$ & $\begin{array}{l}\mathrm{Na}^{+} \\
(\mathrm{ppm})\end{array}$ & $\begin{array}{l}\mathrm{K}^{+} \\
(\mathrm{ppm})\end{array}$ & $\begin{array}{l}\mathrm{Ca}^{2+} \\
(\mathrm{ppm})\end{array}$ & $\begin{array}{l}\mathrm{Mg}^{2+} \\
(\mathrm{ppm})\end{array}$ & $\begin{array}{l}\mathrm{Cl}^{-} \\
(\mathrm{ppm})\end{array}$ & $\begin{array}{l}\mathrm{SO}_{4}^{2-} \\
(\mathrm{ppm})\end{array}$ & $\begin{array}{l}\mathrm{CO}_{3}{ }^{2-} \\
(\mathrm{ppm})\end{array}$ & $\begin{array}{l}\mathrm{HCO}_{3}{ }^{-} \\
(\mathrm{ppm})\end{array}$ \\
\hline 1 & 8.1 & 26 & 435 & 278.4 & 128.6 & 27.7 & 15 & 31.7 & 12 & 47.9 & 21.1 & 0 & 159.5 \\
\hline 2 & 6.9 & 27 & 572 & 366.1 & 128.7 & 70 & 7.5 & 35.7 & 9.6 & 86.1 & 30.7 & 0 & 116 \\
\hline 3 & 7.2 & 26 & 404 & 258.6 & 148.4 & 26.2 & 14 & 35.7 & 14.4 & 33.5 & 27.2 & 0 & 174 \\
\hline 4 & 7.4 & 26 & 2,210 & $1,414.4$ & 247.3 & 450 & 47.5 & 23.8 & 45.7 & 363.7 & 87.7 & 116 & 507.5 \\
\hline 5 & 7.4 & 27 & 1,099 & 703.4 & 296.8 & 157 & 50 & 43.6 & 45.7 & 90.9 & 52.2 & 87 & 362.5 \\
\hline 6 & 7.4 & 24 & 1,267 & 810.9 & 286.9 & 175 & 9.5 & 59.5 & 33.7 & 86.1 & 33.8 & 0 & 536.5 \\
\hline 7 & 7.7 & 26 & 2,330 & $1,491.2$ & 484.9 & 260 & 42 & 135 & 36 & 469 & 94.2 & 58 & 391.5 \\
\hline 8 & 7.6 & 25 & 864 & 553 & 227.5 & 107 & 1.2 & 27.8 & 38.5 & 67 & 33 & 87 & 304.5 \\
\hline 9 & 7.6 & 26 & 1,031 & 659.8 & 306.7 & 95 & 4.2 & 67.5 & 33.6 & 100.5 & 73.7 & 0 & 348 \\
\hline 10 & 7.3 & 25 & 1,449 & 927.4 & 286.9 & 160 & 90 & 35.7 & 48.1 & 114.9 & 48.9 & 0 & 478.5 \\
\hline 11 & 7.1 & 26 & 1,393 & 891.5 & 336.5 & 172 & 62 & 95.2 & 24 & 167.5 & 46.4 & 0 & 348 \\
\hline \multicolumn{14}{|l|}{12} \\
\hline 13 & 7.8 & 26 & 414 & 265 & 168.3 & 22.7 & 11.2 & 51.6 & 9.6 & 28.7 & 23.7 & 0 & 188.5 \\
\hline 14 & & & 804 & 514.6 & 247.4 & 70 & 8 & 75.4 & 14.4 & 57.4 & 41.4 & 0 & 290 \\
\hline 15 & 7.8 & 26 & 840 & 537.6 & 277.1 & 90 & 5 & 87.3 & 14.4 & 90.9 & 43.8 & 0 & 290 \\
\hline 16 & 7.8 & 27.6 & 649 & 415.4 & 257.3 & 60 & 4.7 & 71.4 & 19.2 & 67 & 33 & 0 & 275.5 \\
\hline 17 & 7.4 & 28 & 324 & 207.4 & 138.6 & 20.5 & 4 & 39.7 & 9.6 & 23.9 & 23.6 & 0 & 145 \\
\hline 18 & 7.4 & 27 & 851 & 544.6 & 289.1 & 20 & 10.5 & 73 & 26 & 95 & 43.9 & 20 & 275 \\
\hline 19 & 7.5 & 27 & 388 & 248.3 & 204.8 & 27 & 3 & 53.2 & 17.5 & 50.1 & 30.2 & 0 & 153 \\
\hline 20 & 7.4 & 27 & 506 & 323.8 & 278.9 & 25 & 3 & 60.3 & 31.3 & 60.2 & 51.1 & 0 & 190 \\
\hline 21 & 7.8 & 26 & 820 & 524.8 & 207.8 & 90 & 7.7 & 55.6 & 16.8 & 52.6 & 40.7 & 0 & 406 \\
\hline 22 & 7.4 & 26 & 1,288 & 824.3 & 227.5 & 162 & 97 & 35.7 & 33.7 & 124.4 & 34.9 & 0 & 493 \\
\hline 23 & 7.6 & 26 & 325 & 208 & 128.7 & 19.5 & 132 & 39.7 & 7.2 & 23.9 & 26 & 0 & 145 \\
\hline 24 & 7.6 & 26 & 1,213 & 776.3 & 435.4 & 142 & 16.5 & 107 & 40.8 & 110.1 & 29.3 & 0 & 551 \\
\hline 25 & 7.3 & 26 & 616 & 394.2 & 267.3 & 42 & 8 & 91.3 & 9.6 & 38.3 & 28.4 & 0 & 290 \\
\hline 26 & 7.4 & 26 & 703 & 449.9 & 227.6 & 52 & 11 & 67.5 & 14.4 & 47.9 & 29.5 & 0 & 319 \\
\hline 27 & 7.4 & 24 & 1,197 & 766.1 & 435.3 & 100 & 14 & 91.3 & 50.5 & 124.4 & 63.4 & 0 & 333.5 \\
\hline 28 & 7.3 & 26 & 761 & 487 & 257.3 & 50 & 14 & 75.4 & 16.8 & 47.9 & 32.1 & 0 & 188.5 \\
\hline 29 & 7.4 & 26 & 803 & 513.9 & 237.5 & 92 & 35 & 63.5 & 19.2 & 52.6 & 24.4 & 0 & 377 \\
\hline 30 & 7.4 & 28 & 672 & 430.1 & 237.5 & 62 & 10.5 & 59.5 & 21.6 & 71.8 & 34.7 & 0 & 261 \\
\hline 31 & 7.1 & 4.1 & 925 & 592 & 346.3 & 55 & 2.2 & 87.3 & 31.2 & 196.2 & 32.7 & 0 & 159.5 \\
\hline 32 & 7.4 & 27 & 358 & 229.1 & 168.2 & 19 & 2.2 & 43.6 & 14.4 & 23.9 & 24.4 & 0 & 174 \\
\hline 33 & 7.1 & 28 & 682 & 436.5 & 227.6 & 65 & 7.7 & 55.6 & 21.6 & 71.8 & 41.4 & 0 & 261 \\
\hline 34 & 7.9 & 29 & 265 & 169.6 & 138.5 & 13.7 & 1.2 & 23.8 & 19.2 & 43.1 & 26.6 & 0 & 87 \\
\hline 35 & 7.1 & 25 & 1,026 & 656.6 & 356.2 & 57 & 2.7 & 75.4 & 40.9 & 177.1 & 59 & 0 & 261 \\
\hline 36 & & & 366 & 234.2 & 168.2 & 17.2 & 1 & 39.7 & 16.8 & 9.6 & 27.1 & 0 & 174 \\
\hline 37 & 7.4 & 25 & 648 & 414.7 & 178.1 & 16.5 & 0.5 & 47.6 & 14.4 & 43.1 & 32.2 & 87 & 174 \\
\hline 38 & 6.9 & 7.6 & 1,322 & 846.1 & 623.4 & 40 & 0.7 & 147 & 62.5 & 234.5 & 159.7 & 0 & 130.5 \\
\hline \multicolumn{14}{|l|}{39} \\
\hline 40 & 7.7 & 29 & 755 & 483.2 & 346.3 & 20 & 0.7 & 59.5 & 48.1 & 90.9 & 66.8 & 0 & 232 \\
\hline 41 & 7.4 & 26 & 765 & 489.6 & 247.4 & 8.2 & 10 & 63.5 & 21.6 & 100.5 & 58.5 & 0 & 203 \\
\hline 42 & 7.2 & 25 & 813 & 520.3 & 287 & 77 & 5.5 & 75.4 & 24 & 90.9 & 47 & 0 & 275.5 \\
\hline 43 & 7 & 25 & 997 & 638.1 & 277 & 95 & 3 & 59.5 & 31.2 & 81.4 & 49.4 & 0 & 319 \\
\hline 44 & 7.1 & 27 & 854 & 546.6 & 267.1 & 85 & 1.5 & 55.6 & 31.2 & 114.9 & 44 & 0 & 217.5 \\
\hline 45 & 7.4 & 27 & 579 & 370.6 & 217.7 & 37 & 1 & 43.6 & 26.4 & 52.6 & 36.7 & 0 & 217.5 \\
\hline 46 & 7.4 & 23 & 639 & 409 & 227.6 & 52 & 2.5 & 67.5 & 14.4 & 47.9 & 39.7 & 0 & 290 \\
\hline 47 & 7.6 & 29 & 1,195 & 764.8 & 257.2 & 137 & 2.7 & 39.7 & 38.5 & 201 & 49.1 & 0 & 304.5 \\
\hline
\end{tabular}


Table 3 continued

\begin{tabular}{|c|c|c|c|c|c|c|c|c|c|c|c|c|c|}
\hline $\begin{array}{l}\text { Sample } \\
\text { No }\end{array}$ & $\mathrm{pH}$ & $\begin{array}{l}\text { Temperature } \\
\left({ }^{\circ} \mathrm{c}\right)\end{array}$ & $\begin{array}{l}\mathrm{EC}(\mu \mathrm{s} / \\
\mathrm{cm})\end{array}$ & $\begin{array}{l}\text { TDS } \\
(\mathrm{ppm})\end{array}$ & $\begin{array}{l}\mathrm{TH} \\
(\mathrm{ppm})\end{array}$ & $\begin{array}{l}\mathrm{Na}^{+} \\
(\mathrm{ppm})\end{array}$ & $\begin{array}{l}\mathrm{K}^{+} \\
(\mathrm{ppm})\end{array}$ & $\begin{array}{l}\mathrm{Ca}^{2+} \\
(\mathrm{ppm})\end{array}$ & $\begin{array}{l}\mathrm{Mg}^{2+} \\
(\mathrm{ppm})\end{array}$ & $\begin{array}{l}\mathrm{Cl}^{-} \\
(\mathrm{ppm})\end{array}$ & $\begin{array}{l}\mathrm{SO}_{4}{ }^{2-} \\
(\mathrm{ppm})\end{array}$ & $\begin{array}{l}\mathrm{CO}_{3}^{2-} \\
(\mathrm{ppm})\end{array}$ & $\begin{array}{l}\mathrm{HCO}_{3}{ }^{-} \\
(\mathrm{ppm})\end{array}$ \\
\hline 48 & 7.6 & 23 & 546 & 349.4 & 197.9 & 47 & 7.7 & 47.6 & 28.8 & 81.4 & 41.3 & 0 & 435 \\
\hline 49 & 7.4 & 25 & 1,227 & 785.3 & 455.2 & 77 & 2.5 & 107 & 45.7 & 110.1 & 161.2 & 0 & 406 \\
\hline 50 & 7.3 & 29 & 346 & 221.4 & 158.3 & 17.2 & 0.3 & 39.7 & 14.4 & 23.9 & 14.8 & 0 & 159.5 \\
\hline 51 & 7.4 & 26 & 1,155 & 739.2 & 188 & 157 & 10.2 & 35.7 & 24 & 162.7 & 26.8 & 0 & 348 \\
\hline 52 & 7.4 & 27 & 1,071 & 685.4 & 247.4 & 90 & 47.5 & 67.5 & 19.2 & 81.4 & 17.7 & 0 & 217.5 \\
\hline 53 & 7.1 & 29 & 444 & 284.2 & 158.3 & 19.5 & 0.3 & 43.6 & 12 & 57.4 & 12.6 & 0 & 116 \\
\hline 54 & 6.7 & 29 & 1,001 & 640.6 & 415.6 & 42 & 3.5 & 103 & 38.4 & 172.3 & 14.8 & 0 & 188.5 \\
\hline 55 & 7.1 & 28 & 832 & 532.5 & 306.7 & 25.2 & 0.3 & 63.5 & 36.1 & 110.1 & 73.1 & 0 & 290 \\
\hline 56 & 7.1 & 29 & 601 & 384.6 & 296.8 & 19 & 0 & 63.5 & 33.7 & 47.9 & 19.6 & 0 & 232 \\
\hline 57 & 7.3 & 28 & 490 & 313.6 & 148.4 & 24.2 & 2.2 & 39.7 & 12 & 28.7 & 8 & 0 & 275.5 \\
\hline 58 & 7.4 & 27 & 614 & 393 & 178.1 & 60 & 1.2 & 43.6 & 16.8 & 57.4 & 15.7 & 0 & 246.5 \\
\hline
\end{tabular}

Fig. 5 Sample locations and lithologs. Lithologs of ten different boreholes, which represent different geologic horizons, are shown

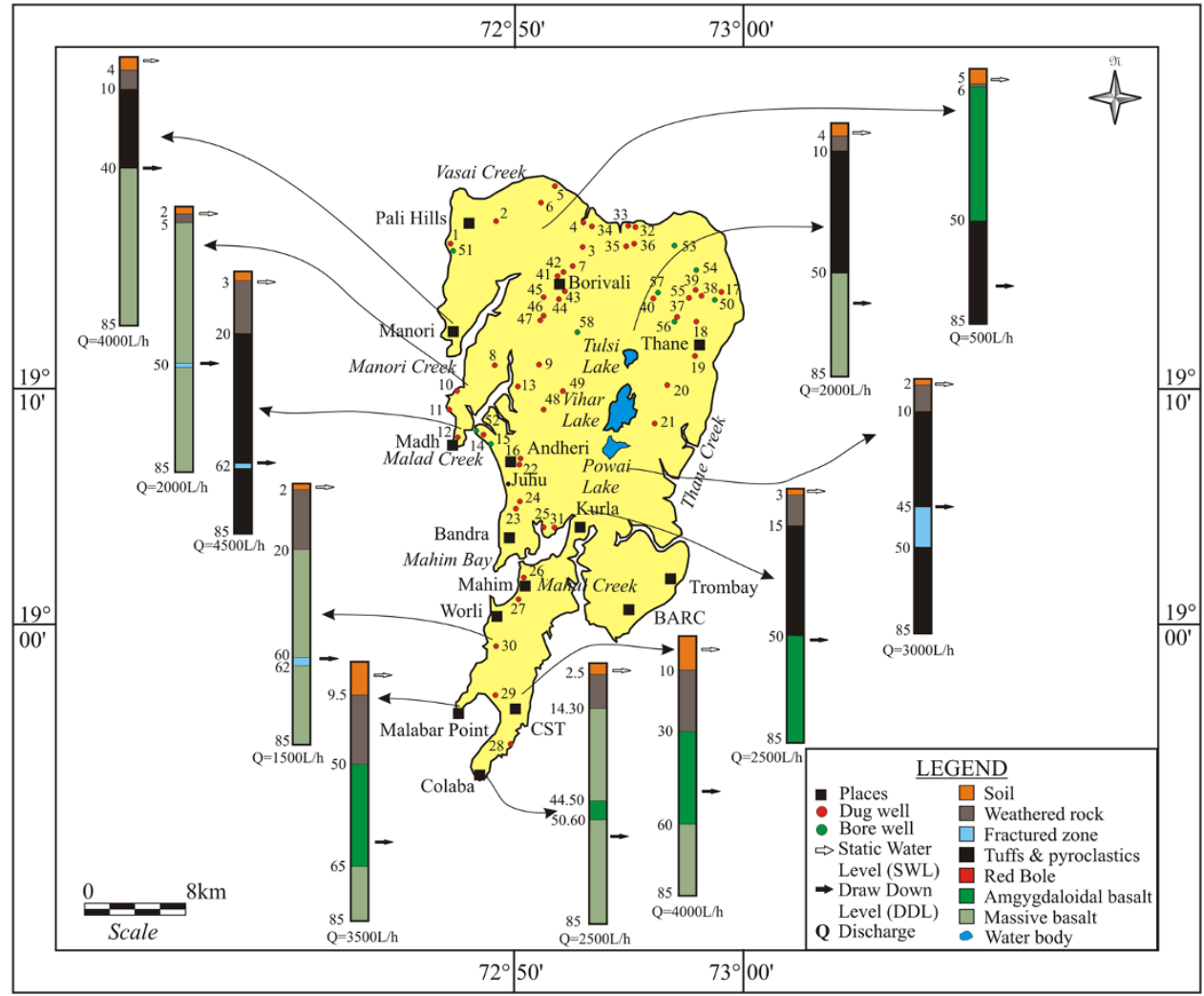

Malwani and Manori trachyte acts as the medium depth aquifer. In the northern parts of the Thane Creek amygdaloidal basalt occurs as the medium depth aquifer.

Along the contact with the deep aquifer and within the medium aquifer, fractures and red boles can be seen. This increases the storativity and transmissivity of the basaltic rocks. The jointed and fractured zones are seen more commonly in amygdaloidal basalt than compact basalt. But in the case of tuffaceous rocks which are mainly seen in the northern flanks of Borivali National Park, jointing and fracturing enhance weathering, which in turn reduce the transmissivity of aquifer material due to the formation of clay. The thickness and lithology of medium depth aquifer range from 15 to $40 \mathrm{~m}$.

From the detailed study of lithology, it can be concluded that the shallow aquifers are extending up to $15 \mathrm{~m} \mathrm{bgl}$, while the lithology of the medium depth aquifer mainly changes from one location to another. The various types of medium depth aquifers include massive basalt, amygdaloidal basalt, trachyte, pyroclastics and tuffs. Of the 
Table 4 Sample location vis-à-vis landforms

\begin{tabular}{llll}
\hline & Denudational & Fluvial & Coastal \\
\hline Sample location no. & $1,32,33,34,35,37,39$, & $3,4,6,7,9,10,11,12,16,17$, & $2,5,8,13,14,15,52$ \\
& $40,51,53,54,55,56,57$ & $18,19,20,21,22,23,24,25,26$, & \\
& & $27,28,29,30,31,36,38,41,42$, & \\
& $43,44,45,46,47,48,49,50,58$ \\
\hline
\end{tabular}

different types of aquifers, the most important aquifer influenced by geomorphology is the shallow aquifer. In fact, shallow aquifers, and to larger extent medium aquifers, are subsurface extensions of the landforms. An understanding of these landforms will help in understanding the shallow aquifer system.

\section{Discussion and conclusions}

Studies of landforms of any area have predominant importance in understanding the hydrogeology of that particular area. The landforms of Mumbai are considerably modified by anthropogenic activities which altered the groundwater regime. Therefore, the evaluation of groundwater scenario of Mumbai Island with respect to geomorphology is very necessary as the demand for quantity of freshwater increases whereas the quality decreases day after day (Haque et al. 2012).

Geomorphology of the area gives an insight into the landforms, which in turn, influences the occurrence as well as the quality of groundwater. The studies show that the denudational landforms are, generally, areas of greater surface runoff whereas coastal and fluvial landforms represent regions of relatively high infiltration. Mesa, linear ridges, simple slope and residual hills have steep slopes which enhance the runoff process and hence these zones will never entertain the process of groundwater occurrence. In contrast, alluvial plains, fans and deltaic plains are favorable sites for infiltration and are capable of forming groundwater reservoirs since these are composed of loose unconsolidated sediments. Deltaic plain in the study area is not marine, but lacustrine in origin. The presence of water throughout the year in the area facilitates groundwater infiltration. Coastal landforms are often favorable sites of groundwater occurrence, but are often invaded by marine water. Hence deterioration in groundwater quality occurs due to the invasion. The quality deteriorates more near to the salt pans. The aquifers of this area are enriched in salt content round the year. Groundwater prospect in mudflats also shows the same nature due to the presence of brackish water and high presence of litter. So in the study area, groundwater occurrence increases in the order: denudational-fluvial-coastal landforms whereas the order is reversed as far as the quality of water is concerned.

The average slope map of the study area shows that most of the area has very low slope $\left(<5^{\circ}\right)$. The low-slope category is mainly in areas of fluvial landforms that cover about $56 \%$ of the study area. The denudational landforms have an average slope slightly higher than other landforms and are located in the inland. In general, on the basis of slope, the areas having slopes greater than $15^{\circ}$ can be categorized as runoff zones and those below $5^{\circ}$ as storage zones. The runoff zone covers $33 \%$ of the study area whereas the storage zone covers $58 \%$ indicating the relevance of slope towards groundwater occurrence.

Hydrogeomorphology of the study area also has the same result. Linear ridges, residual hills, cuestas and mesa which are of denudational nature enhance the runoff process whereas alluvial fan and pediments of fluvial origin greatly enhance infiltration process. The beaches, salt pans and mudflats are marine landforms, which continuously deteriorate the quality of water.

The classification of landforms on the basis of hydrogeomorphic characteristics is further validated with the hydrogeochemistry and subsurface geology. Both the studies validate the hydrogeomorphic classification of landforms studied through field work and remote sensing techniques. The hydrogeochemistry of denudational landforms reveals that the quality of water is good, but replenishment during monsoon is very small. Hence, these landforms have to be preserved from deterioration and are ideal target for artificial recharge for a better tomorrow in Mumbai Island. Continuous contour trenches (CCT), loose boulder structures (gully plugs) are the most suitable structures for hilly area as these structures will function initially as soil conservation structure and subsequently improve the soil moisture retention and also enhance the recharge to groundwater. These structures will also improve sustainability of springs thereby improving water supply scenario in the small hamlets situated in hilly areas. But fluvial landforms have good potential to hold water and the quality of water is usually good. This landform is the feeder for domestic supply of water to the majority of the population in the city and has to be protected from deterioration. Marine landforms have good storativity, but are frequently invaded by seawater. 
Borehole data reveal that three types of aquifers exist in Mumbai basaltic terrain: shallow, medium and deep aquifer. There is a considerable difference in the hydrogeochemistry of water samples collected from shallow, medium and deep aquifers. Dug wells usually tap the shallow and medium level aquifers whereas bore wells are confined to deep level aquifers. Shallow level aquifers are controlled by the geomorphology of the area whereas medium and deep aquifers are controlled by the subsurface geology. Hence, shallow level aquifers are more discussed in this part. Shallow level aquifers exist in the tune of 2-5 m depth. Majority of the population depends on these aquifers. The presence of these aquifers at these depths is determined by the geomorphology. The denudational and fluvial landforms are usually marked by soil at the top followed by a weathered horizon. The thickness of weathered horizon is less in denudational landforms when compared to fluvial. Marine landforms encounter massive or amygdaloidal basalts soon after the top soil. Usually these are the areas characterized by rocky beaches. The subsurface data reveal that the shallow level aquifers are easily accessible for deterioration where as the deeper levels are less vulnerable. Hence, considerable attention has to be done on shallow level aquifers.

The study as a whole shows that an understanding of the geomorphology of any area helps in the mapping of the aquifer and the quality of the water therein. Realizing this situation, it is imperative that runoff which is going waste should be harvested and utilized for augmenting depleted aquifers.

Acknowledgments This work forms a part of the M.Tech dissertation carried out by the first author. The first author thanks the Indian Institute of Technology (IIT) Bombay for providing scholarship during the course. We thank the authorities of Brihan Mumbai Corporation (BMC) for providing subsurface data.

Open Access This article is distributed under the terms of the Creative Commons Attribution License which permits any use, distribution, and reproduction in any medium, provided the original author(s) and the source are credited.

\section{References}

Abiola O, Enikanselu PA, Oladapo MI (2009) Groundwater potential and aquifer protective capacity of overburden units in Ado-Ekiti, southwestern Nigeria. Int J Phys Sci 4(3):120-132

Agashe RM (1989) A review of activities and achievements of Central Ground Water Board in Maharashtra. Theme paper: Sem. On role of groundwater in use of water resource in Maharashtra state, Nagpur. Joint Publ: Central Ground Water Board, Dept. of Irrigation-Govt. of Maharashtra and GSDA 36p

Anbazhagan S, Nair AM (2004) Geographic information system and groundwater quality mapping in Panvel Basin, Maharashtra, India. Environ Geol 45:753-761
APHA (American Public Health Association) (1998) Standard methods for the examination of water and wastewater, 20th edn. American Public Health Association, Washington, p 20005

Auden JB (1949) Dykes in Western India-a discussion of their relationships with the Deccan Traps. Trans Nat Inst Sci India VIII:123-157

Barron OV, Barr AV, Donn MJ (2012) Effect of urbanization on the water balance of a catchment with shallow groundwater. J Hydrol doi: 10.1016/j.jhydrol.2012.04.027

Brockeroff M (2000) An urbanizing world. Popul Bull 55(3):1-57

Buist G (1857) Geology of the island of Bombay, geological papers on Western India, Bombay. Education Society's press, Bombay, pp 169-206

Carter HJ (1857) Geology of the Island of Bombay. Geol. Papers on W. India. Bombay Education Society's press, Bombay, pp 116-168

Cook PG (2003) A guide to regional groundwater flow in fractured rock aquifers. CSIRO, Australia, p 107

Gopal B (2012) Future of wetlands in tropical and subtropical Asia, especially in the face of climate change. Aquat Sci. doi:10.1007/ s00027-011-0247-y

Government of Maharashtra (1993) Maharashtra groundwater: regulation of drinking water purposes, Act 1993, chapter 2, clause 3. Government of Maharashtra, Mumbai, p 2. http://www.ielrc.org/ content/e9301.pdf. Accessed 5 Mar 2014

Gupta S (2009) Groundwater information. Greater Mumbai district, Maharashtra. Central Ground Water Board, Nagpur, p 10

Haque SJ, Onodera S, Shimizu Y (2012) An overview of the effects of urbanization on the quantity and quality of groundwater in South Asian megacities. Limnology. doi:10.1007/s10201-0120392-6

Kamble SR, Vijay R (2011) Assessment of water quality using cluster analysis in coastal region of Mumbai, India. Environ Monit Assess 178:321-332

Krishnan MS (1960) Geology of India and Burma. Higginboothams, Madras, p 604

Krishnan MS (1982) Geology of India and Burma, IVth edn. Higginbothams, Madras, p 536

Limaye SD (2010) Review: groundwater development and management in the Deccan Traps (basalts) of western India. Hydrogeol J 18:543-558

Maiti S, Erram CV, Gupta G, Tiwari RK (2012) ANN based inversion of DC resistivity data for groundwater exploration in hard rock terrain of western Maharashtra (India). J Hydrol 464-465: 294-308

Mondal NC, Singh VP, Singh VS, Saxena VK (2010) Determining the interaction between groundwater and saline water through groundwater major ions chemistry. J Hydrol 388:100-111

MPCB (2011) Water quality for the year 2007-2008 under GEMS MINARS project. Maharashtra Pollution Control Board, Mumbai. Data downloaded on 20 March 2011 http://www.mpcb.gov. in/envtdata/InnerPg_gmsmnrs32007.php. Accessed 20 Mar 2011

Murthy RC, Rao YR, Inamdar AB (2001) Integrated coastal management of Mumbai metropolitan region. Ocean Coast Manag 44:355-369

Naik PK, Dehury BN, Tiwari AN (2007) Groundwater pollution around an industrial area in the coastal stretch of Maharashtra State, India. Environ Monit Assess 132:207-233

Nair KS (2009) An Assessment of the impact of climate change on the megacities of India and of the current policies and strategies to meet associated challenges, fifth urban research symposium 2009, Marseille, France

Owen R (1847) On the Batracholite, indicative of a small species of frog (from Bombay). Q J Geol Soc Lond 3:224-225

Pascoe EH (1964) A manual of geology of India and Burma, 3rd edn. Govt. of India publ, New Delhi, pp 1345-2130 
Rani VR (2004) Hydrogeochemistry of coastal wetlands and inland aquifers of Mumbai and Mumbra-Belapur region, Maharashtra. M.Tech thesis (Unpublished). Indian Institute of Technology Bombay, Mumbai, p 260

Rao RCS, Sahasrabudhe YS, Deshmukh SS, Raman R (1978) Distribution, structure and petrography of the Deccan Traps, India. Rep Geol Surv India (Unpub)

Sabnis MM (1984) Studies of some major and minor elements in the polluted Mahim River estuary (PhD. thesis). University of Bombay (now Mumbai), Mumbai, p 288

Sekovski I, Newton A, Dennison WC (2012) Megacities in the coastal zone: using a driver-pressure-state-impact-response framework to address complex environmental problems. Estuar Coast Shelf Sci 96:48-59

Sethna SF (1981) Geology around Bombay: some intriguing problems. Mem Geol Soc Ind Bangalore 3:279-286

Sethna SF (1999) Geology of Mumbai and surrounding areas and its position in the Deccan Volcanic Stratigraphy, India. J Geol Soc India 53:359-365

Shah SD, Parthasarathy A (1982) Deccan volcanics: rock materials and rock masses characteristics and their significance in engineering geology in Deccan Volcanism. Mem Geol Soc India Bangalore 3:233-243

Shankar RMN, Mohan G (2006) Assessment of the groundwater potential and quality in Bhatsa and Kalu river basins of Thane district, western Deccan Volcanic Province of India. Environ Geol 49:990-998

Sheth HC (1998) A reappraisal of the coastal Panvel Deccan Flexure, Deccan Traps, as a listric-fault-controlled reverse drag structure. Tectonophysics 294:143-149
Sheth HC, Pande K, Bhutani R (2001) ${ }^{40} \mathrm{Ar}^{39}$ Ar ages of Bombay trachytes: evidence for a Palaeocene phase of Deccan Volcanism. Geophys Res Lett 28:3513-3516

Sukeshwala RN (1953) Notes on the field occurrence and petrography of the rocks of the Bombay Island, Bombay. Trans Min Met Soc India 50:101-126

Sukeshwala RN, Poldervaart A (1958) Deccan basalts of Bombay area, India. Geol Soc Am Bull 69:1475-1494

Thornbury WD (1990) Principles of geomorphology. Wiley, New York

Tirumalesh K, Shivanna K, Sriraman AK, Tyagi AK (2010) Assessment of quality and geochemical processes occurring in groundwaters near central air conditioning plant site in Trombay, Maharashtra, India. Environ Monit Assess 163:171-184

Todd DK (1980) Groundwater hydrology, II edn. John Wiley \& Sons, New York

United Nations (2010) World population prospects: the 2008 revision and world urbanization prospects: the 2009 revision. Population Division of the Department of Economic and Social Affairs of the United Nations Secretariat, New York. http://esa.un.org/ wup2009/unup

Williams E (1953) Fossils and the distribution of chelyid turtles. "Hydraspis" leithii (Carter) in the Eocene of India is a pelomedusid. Breviora (Mus. Comp. Zoology, Cambridge, Mass) 13:8

Zingde MD, Sabnis MM (1989) Flushing characteristics of Mahim River estuary. Adv Biosci 8:1-7 